\title{
Question Generating Supported by Blended Learning Platform: Issues of Social Justice for Environmental Education
}

\author{
John Oversby ${ }^{1}$, Jude Sanders ${ }^{2}$, Corrienna Abdul Talib ${ }^{3 *}$, Ng Khar Thoe ${ }^{4}$, Norizan Esa ${ }^{5}$ \\ ${ }^{1}$ Science Education Futures, UK \\ 2 Hibernia College, IRELAND \\ ${ }^{3}$ Universiti Teknologi Malaysia, MALAYSIA \\ ${ }^{4}$ SEAMEO RECSAM, MALAYSIA \\ ${ }^{5}$ Universiti Sains Malaysia, MALAYSIA
}

Received 2 April 2018 • Revised 14 January 2019 • Accepted 20 January 2019

\begin{abstract}
An element of social justice to be promoted through Environmental Education (EE) is that it questions some features of existing power relationships in education and community. In this paper, we describe an unusual and versatile assessment procedure supported by the blended learning platform that provides a wealth of insight into thinking. It has been trialed with secondary science students in the UK, and with STEM teacher educators in Uruguay and through Edmodo social learning platform under SEAMEO networking school project initiative. The study discovered that educators provide only a few questions, whereas younger participants provide many. We will also describe a session with Uruguayan STEM teacher educators learning to use this unusual method in their teacher training programs. In conclusion, the question generating that is proposed in this study was found to be a useful method for formative assessment both for pupils and for teachers in training especially suited when it is supported by blended learning platforms and digital tools. It provides insights into the way in which participants are thinking about a content area, giving information about the depth and security of understanding and potentially revealing misconceptions.
\end{abstract}

Keywords: assessment, secondary students, science education supported by blended learning, social justice

\section{INTRODUCTION}

Young learners should be exposed to the knowledge required for their future work and assessed to see if they have absorbed that knowledge (as well as accepting explicitly or implicitly that knowledge relationship and the power behind it). Perhaps, at another extreme, is a view that young learners might be active participants in the knowledge communication game, and might be given, some power to themselves to exercise some independence. We emphasise that there is probably a spectrum of views regarding various global issues such as Environmental Education (EE) integrating Information and Communication Technology (henceforth abbreviated as EE-ICT) that is the focus of this study, with factors such as the maturity of the learners in responding to the questions.

\section{Review of Related Literature}

MacLellan and Soden (2003), among many others, explore these global issues related to social justice for Environmental Education supported by ICT very well. Nevertheless, if one aims to prepare young learners for future adult life, then fail to engage them in taking a more active role in learning and assessment could count as a failure of school education. It would be a matter of social justice through an innovative method that is open-ended question generation and learners' views are valued at different levels. The method was developed from White and

(C) 2019 by the authors; licensee Modestum Ltd., UK. This article is an open access article distributed under the terms and conditions of the Creative Commons Attribution License (http://creativecommons.org/licenses/by/4.0/).

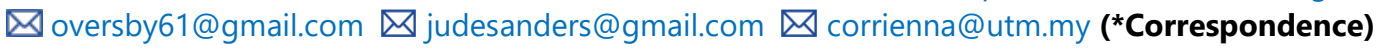




\section{Contribution of this paper to the literature}

- This paper aims to present a method for formative assessment supported by the blended learning platform for learners/educators.

- Peer discussion helps develops metacognition of participants.

- The role of learners in developing assessment techniques should be considered in environmental education integrating ICT.

Gunstone (1992) with emphasis that learners should be considered in learning and assessment process. In addition, generating questions will encourage students' curiosity to think critically while participating in the learning process (Corrienna \& Mohd Imran Arif, 2016).

In a study employing the think-pair-share activity, students were required to generate two questions each from the topic being learned, and also select the two best questions from a group that was formed by five pairs each (Cooper, 2018). This form of peer assessment also doubles up as formative assessment as the teacher can evaluate the prior knowledge or progress of students from the questions that are generated and selected, depending on which stage of the lesson the questions are generated.

Lombard and Schneider (2013) investigated how student-generated questions can be improved by the availability of authentic science resources in inquiry learning. As the scientific authority is separated from pedagogic authority, a measure of student autonomy is possible within the student-teacher power relations. Access to authentic scientific resources provides the opportunity to generate better questions, encouraging students to evaluate, select and process the information from these resources in generating their questions. The students in the study were able to generate better questions as they become more involved with these resources, in student-student interactions over a long period of time.

Virgin (2015) argued that students will be more curious and engaged with content when they are involved in generating questions. The opportunity for connecting learning, where they are able to relate what they learn in class with their out of class activities, will encourage them to explore more questions and possibilities. This can help develop skills of metacognition, as well as generating divergent and convergent questions, thus also developing their higher order thinking skills. Low performing students appeared to have benefited more from generating questions compared to their higher performing counterpart (Berry \& Chew, 2015). Student-generated questions have been tried with Key Stage 2 students (Dunlop, Compton, Clarke, \& McKelvey-Martin, 2015) in which after given a stimulus, students volunteered questions. The class then voted on the questions they would like to explore. The teacher then decides on the question that is suitable, based on what the students already know. Their findings showed students are more engaged in learning, and continued their discussion and extended their investigations beyond the school time. The students reported that they learned more about science and even engaged in intergenerational sharing with their parents.

These examples demonstrate how questions generated by students can be used to assess their learning and how much they have understood the material learned. It can also be used to design future learning, based on an assessment of students' mastery of the content through the types of questions generated, those investigated and the further questions generated as a result. Student-generated questions therefore, may be considered a methodology for formative assessment as the questions posed are based on the depth of understanding of the students at that point of their learning. Formative assessment has been defined as a combination of criterionreferenced and student-referenced assessment (Harlen \& Mary James, 1997), that measures the student's progress in terms of content and skills at a specific point of their learning. Formative assessment is used diagnostically to plan for the specific pupil's learning in the next stage (Black \& Wiliam, 2005). Thus, formative assessment should be an integral component of teaching, integrated throughout the learning process to enable the student to progress accordingly and for the teacher to plan for assisting the progress of the student Black et al. (2004).

In addition to student-generated questions are a methodology that can be used to improve students' knowledge and awareness about the environment, as specific content. In a study by Fauville (2017), students generated questions from their online interaction with a marine scientist on matters relating to the ocean. This occurred after a virtual laboratory and a virtual lecture session delivered through a specially designed online platform. Students were provided with the opportunity to learn marine science from the scientist expert and presented questions that could possibly only be answered by scientists in the field, but possibly not by their teachers. This experience provided them with knowledge about marine science, the oceans, the scientific method and also opportunities to pose questions on environmental issues related to the ocean. With such an arrangement, ICT is used to provide a platform for interaction between students and experts and the resulting asynchronous interaction allows for further student investigation of the content before connecting with the scientist, and thus developing their mastery of knowledge about the ocean. 


\section{Overview and Focus of Study}

This questions generation method was trialed by the first and second authors in the UK and Uruguay between 2015 to 2016. From 2017, it was also piloted through Edmodo social learning platform of SEAMEO networking school project initiative in which the third to fifth co-authors were involved as participants/coordinator/reviewer. They worked in collaboration with the first author who was invited as a consultant to provide input on the topic 'Climate Awareness and Disaster Risk Reduction EDucation' (CADRRED) during the curriculum development workshop conducted in Fiscal year 2015/2016 with an exemplary output reported, e.g. by Montecillo, et al. (2016). The following are the research questions of this study:

1. How could a formative assessment supported by the blended learning platform be implemented to promote Environmental Education (EE) in various countries?

2. Are there exemplary teaching methods using question generating to promote EE-ICT?

3. What are the exemplars of pedagogical content knowledge (PCK) that could be elicited from this question generating technique either conducted face-to-face or supported by blended learning platforms?

\section{METHODOLOGY}

This study involved secondary science students from the UK and STEM teacher educators from Uruguay as well as SEAMEO blended learning to show the diversity of study involving nationalities from different countries. The researchers designed possible responses to questions set within a specific context and participants were asked to create potential questions to which the provided answers would be appropriate. Secondly, the participants were required to rank the questions generated in order of difficulty (secondary science students). The researcher used the case study method to obtain the data for this study. Rich qualitative information about classroom processes such as participant interaction can be collected using the case study method (Creswell, 2012).

\section{Question Generating as a Formative Assessment Approach}

The question-generating approach used by researchers used a scaffolding technique designed to stimulate the creation of questions that are relevant to the taught topic and to partially constrain the created questions. This scaffolding technique used the idea of 'partial answers'. The partial answers should be open, or uncertain, enough to provoke a range of potential questions, but not too open as to allow any question. Participants then created as many potential questions for which the partial answer would be appropriate. As a second stage, the questions were collected and the participants were challenged to rank them. Students in the UK were asked to rank the questions in order of the level of knowledge the learner had and STEM teacher educators in Uruguay were asked to rank them in order of content knowledge and/or process knowledge demonstrated. Similar partial answers were used with both groups.

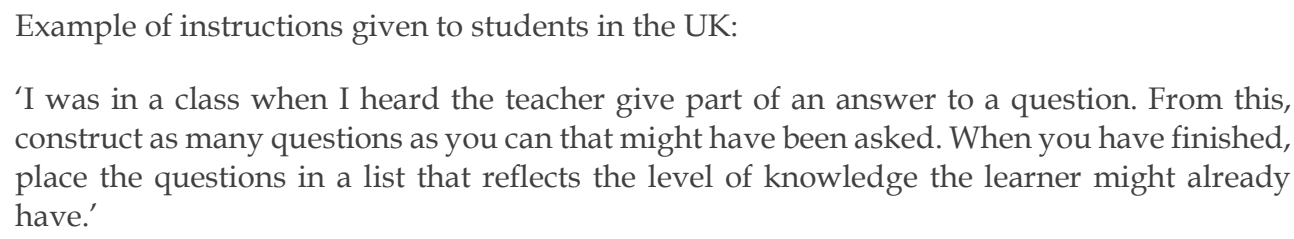

One example of a partial answer given to student participants was: “...because stars give out their own light". Responses from the student group included: a) Why is the sun a star? b) How can we count the stars? c) What is a star made of? Data collected included the range of responses to well-developed partial answers, the lists of rank questions as well as contemporaneous notes on the interactions between students and the discussion and reflections generated in order to provide deeper insight into participant understanding.

\section{Question Generating as A Teaching Method: An Experiment in Uruguay}

During a training course conducted in February 2016, a total of 14 STEM teacher educators in Uruguay (which comprised the entire group of teacher educators in Uruguay) were introduced to this question generating approach as an example of formative assessment. They were encouraged to take part in the activity taking the role of students and asked to reflect on the process and outputs of this method of assessment and to consider how this method might impact the learning process of both teachers in training and their pupils. Data collected included teacher reflections and ranked lists of the generated questions as shown in Table 1 and Table 2. 
Table 1. Example of a Ranked List of Generated Questions from the UK Student Group

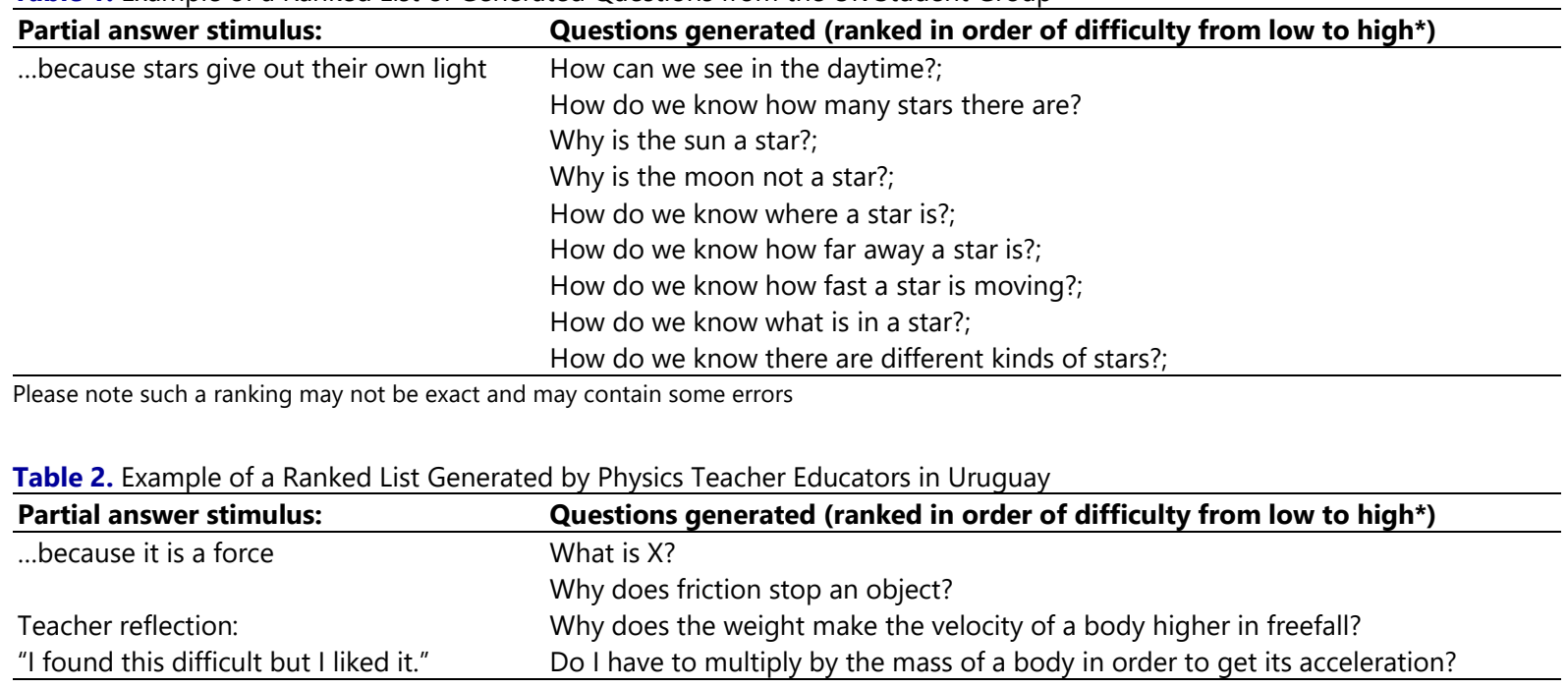

\section{Question Generating as An Approach to Promote Thinking and EE-ICT: An Experience with SEAMEO School Networking Platform}

The first author was also involved in curriculum development workshop conducted under SEAMEO Learning Science and Mathematics Together (LeSMaT) school networking project coordinated by the fourth co-author with some exemplary output as reported in $\mathrm{Ng}$, Devadason and Lay (2016). The question generating and students' reflective journal techniques were included as pedagogical approaches and were piloted in the Edmodo social learning platform since 2016 with illustrative pieces of evidence of online responses to be reported.

\section{FINDINGS}

\section{Question Generating as a Formative Assessment with Exemplars}

With young learners in the UK, especially, many potential questions were generated by this open-ended kind of assessment tasks. The evidence, in the form of the types of questions generated, can be used to assess the depth of understanding and develop metacognition. Peer discussion of the evidence demonstrates different levels of understanding and can provide formative evidence of how the participants are thinking about the topic and their depth of understanding, for example of Environmental Education (EE). It could be a disadvantage that it is not targeted at one specific aspect of understanding, but this is offset by the creativity it unlocks as it is used. Moreover, this activity can be extended to develop metacognition.

After generating the questions, the students were asked to put these questions in order of difficulty -such as which is the hardest question to answer. In groups, they discussed the order of difficulty. This process activates metacognition -builds understanding of what we know and what we do not. Ordering the questions helps them understand the level of difficulty. In addition the discussion generated helps elicit students' reasoning, revealing any potential misconceptions. Collaboration helps build understanding of how different people think as well as thinking critically about the different levels of understanding. This makes such assessment method firmly grounded in the formative fold, rather than summative. But there are those who claim they would not use this method because it does not mirror examination questions. We see this as a positive point, since the metacognition produced is rarely assessed by summative assessment, yet we regard it as an important outcome of the formative process. It is too valuable to let slip simply because it may not fit summative assessment criteria.

\section{Question Generating as A Teaching Method: Experience with Uruguay teacher educators}

During the training course conducted in February 2016, 14 STEM teacher educators in Uruguay consistently noted the transformative nature of the activity, noting how it gave them a different perspective which led to them changing their approach. They also commented on how challenging, they found creating multiple questions in response to the stimulus of a partial answer. They put this down to their normal activity of only creating a single, correct response in class. In addition, they found developing their own partial responses as stimuli for their own 
classes, particularly challenging, tending to focus at first on simple closed question types. The questions they generated were set at a relatively high level, requiring knowledge at High School or University level. However, the teacher educators found the process very engaging and illuminating, helping them see different viewpoints and to think about the content knowledge in different ways:

"I was very entertained by the possibilities! I began making questions, but then I thought about the subject from the students view - where do I put a question about double bonding" (Chemistry specialist from the Uruguay teacher educator group)

Their questions were almost always content focussed assuming a closed question type with one specific answer rather than a range of possible answers. They also tended to focus on just one aspect of a topic, often the most complex aspect, rather than seeing the variety of questions that could lead to a single answer.

Examples of questions generated by Chemistry specialists from Uruguay

- What is the name of the compounds that contain a double bond?

- Why does the structure change in the peptide bond?

- Why is it a planar compound?

- Why it saturated/nonsaturated, e.g., physical properties?

- Why is it reacting with bromine water?

This is potentially influenced by their focus as teacher educators on the specifics of content knowledge rather a student viewpoint which is less informed, but potentially more creative allowing them to see more of the range of possible questions. Participants were easily distracted by criticising the construction of the partial answers, wanting to make them more specific and linking them to specific aspects of content knowledge, e.g., exact definitions or trying to determine the exact piece of content knowledge being 'tested'. They failed to recognise at first that some ambiguity was a valuable asset of a partial answer since it leads to a greater range of potential questions and revealed more about the breadth and depth of student knowledge.

Our data suggest that younger learners find this method of working easier than older learners. They generated a larger variety of question types and looked at the process as well as content. The teacher educator group, however, tended to look for the one correct answer when in fact multiple responses were more appropriate. Peer discussion helped reveal the multiple ways of approaching the topic and what teachers themselves viewed as difficult or interesting. It also provided some transformative learning opportunities (Mezirow, 1991). See below for an example from the Technologists in the Uruguay teacher educator group who demonstrated a shift in their thinking about teaching and learning. Their stimulus was: “...because it amplifies..." When discussing their results with colleagues the following reflection was made:

Something similar happened to us - we found an ambiguous concept of amplification, we were very happy with our questions until the chemists started to ask us questions about the definition... We started by asking some questions for a very basic level:

- Why does the guitar sound louder?

- Why does the circuit in figure A oscillate?

- Why do radios use resonant systems?

- Why do digital circuits have input ranges?

Then we collaborated with the Biology colleague, she asked: "Does the microscope amplify?" We saw the ambiguity of the word 'amplification' there are actually two types - one that augments the power and one which makes the quantity higher. For us, the technical conception means the output signal is greater than the input signal, so this is a different meaning. This shows that a good answer needs to be a little ambiguous to generate good questions are revealing the ambiguity. “

A fuller range of examples linked to EE and Global issues can be found in Table 3. 
Table 3. Examples of Possible Sustainability Science, Mathematics and EE Related Questions Extracted from Responses by Students in the UK

\begin{tabular}{|c|c|c|}
\hline Part of an answer & Pedagogy & Some possible questions \\
\hline \multicolumn{3}{|l|}{ Climate change } \\
\hline $\begin{array}{l}\text { 1.... because humans are burning fossil } \\
\text { fuel. }\end{array}$ & $\begin{array}{l}\text { Promotes the idea of human involvement in } \\
\text { climate change }\end{array}$ & $\begin{array}{l}\text { Why does human activity increase carbon dioxide in the } \\
\text { atmosphere? } \\
\text { Why are fossil fuels running out? }\end{array}$ \\
\hline $\begin{array}{l}\text { 2. ... because we make less carbon } \\
\text { dioxide that way. }\end{array}$ & $\begin{array}{l}\text { Promotes thinking about } \\
\text { action }\end{array}$ & $\begin{array}{l}\text { Why does using public transport reduce carbon dioxide } \\
\text { emissions? } \\
\text { Why does using nuclear reactors affect the carbon dioxide } \\
\text { content of the atmosphere? }\end{array}$ \\
\hline $\begin{array}{l}\text { 3.... because extreme weather events are } \\
\text { dangerous. }\end{array}$ & $\begin{array}{l}\text { Promotes thinking about } \\
\text { impact of extreme weather } \\
\text { events }\end{array}$ & Why does it matter that we have warmer and wetter summers? \\
\hline \multicolumn{3}{|l|}{ Biology } \\
\hline $\begin{array}{l}\text { 4. ... because a flower is not usually } \\
\text { green }\end{array}$ & $\begin{array}{l}\text { Explores the role of flowers in the attraction of } \\
\text { pollinators. Also, points up the need for a plant } \\
\text { to have some green parts to make and store } \\
\text { energy via photosynthesis. }\end{array}$ & $\begin{array}{l}\text { How does a plant attract insects? } \\
\text { Why does a plant need some parts that are green? }\end{array}$ \\
\hline 5. ... because it is a plant & $\begin{array}{l}\text { Explores the role of classification of part of } \\
\text { living things. Also, could be used to look at } \\
\text { plant features and their roles in ecosystems. }\end{array}$ & $\begin{array}{l}\text { Why is there more grass than cows? } \\
\text { What advantage is there for some living things to be green? }\end{array}$ \\
\hline $\begin{array}{l}\text { 6. ... because they are } \\
\text { different species }\end{array}$ & $\begin{array}{l}\text { Apart from mating and reproduction, this } \\
\text { answer looks at issues of classification. }\end{array}$ & $\begin{array}{l}\text { Why cannot cows successfully mate with sheep? } \\
\text { Why must pollen for fertilising an apple comes from a related } \\
\text { apple tree flower? }\end{array}$ \\
\hline \multicolumn{3}{|l|}{ Education for sustainability } \\
\hline $\begin{array}{l}\text { 7. ... because humans are causing } \\
\text { environmental } \\
\text { Change }\end{array}$ & $\begin{array}{l}\text { The impact of humans on the environment is at } \\
\text { the centre of this answer. }\end{array}$ & $\begin{array}{l}\text { What makes a remote wilderness so different from a farm } \\
\text { environment? } \\
\text { Why are some fish becoming extinctor or in short supply? } \\
\text { Why is the earth warming? }\end{array}$ \\
\hline $\begin{array}{l}\text { 8. ... because electricity is not readily } \\
\text { available everywhere }\end{array}$ & $\begin{array}{l}\text { As well as mechanical questions, this can also } \\
\text { relate to access to electrical supply and social } \\
\text { justice. }\end{array}$ & $\begin{array}{l}\text { Why are some human groups so reliant on hand machines and } \\
\text { methods of agriculture? }\end{array}$ \\
\hline \multicolumn{3}{|l|}{ Chemistry } \\
\hline $\begin{array}{l}\text { 9. ... because burning involves both fuel } \\
\text { and oxygen }\end{array}$ & $\begin{array}{l}\text { This emphasises that both parts are essential for } \\
\text { burning. }\end{array}$ & $\begin{array}{l}\text { Why does the gas inside a burner pipe not burn? } \\
\text { Why does oxygen not burn? }\end{array}$ \\
\hline $\begin{array}{l}10 . . . \text { because a solution is a } \\
\text { homogenous mixture (the same all } \\
\text { through) }\end{array}$ & $\begin{array}{l}\text { This distinguishes between such things as } \\
\text { solutions and suspensions. }\end{array}$ & $\begin{array}{l}\text { Why are mixtures of gases also solutions? } \\
\text { Why is a salt solution not a suspension? }\end{array}$ \\
\hline $\begin{array}{l}11 . . . \text { because both solutes } \\
\text { and solvent particles mingle (intermix) } \\
\text { during the dissolving process }\end{array}$ & $\begin{array}{l}\text { This makes the point that both the solute and } \\
\text { the solvent are active in the solution process. }\end{array}$ & How do the particles interact in the dissolving process? \\
\hline $\begin{array}{l}\text { 12.... because some solutes are only } \\
\text { partially soluble in the solvent }\end{array}$ & $\begin{array}{l}\text { Few solutes dissolve in all proportions with a } \\
\text { solvent. }\end{array}$ & Why is there a limit to the solubility of a solute in a solvent? \\
\hline $\begin{array}{l}\text { 13... because reusing is } \\
\text { better than recycling }\end{array}$ & It takes energy to recycle but not to reuse. & $\begin{array}{l}\text { How does it cost energy to make a bag from old discarded pieces } \\
\text { of plastic? }\end{array}$ \\
\hline \multicolumn{3}{|l|}{ Physics } \\
\hline $\begin{array}{l}\text { 14. ... because sound can travel through } \\
\text { solids, liquids, and gases, but not a } \\
\text { vacuum }\end{array}$ & $\begin{array}{l}\text { This answer points to the importance of a } \\
\text { medium for sound to travel. }\end{array}$ & Why could we not hear a spacecraft exploding in space? \\
\hline $15 . \ldots$ because of power $=$ work/time & $\begin{array}{l}\text { At first sight, this could be a simple calculation } \\
\text { issue. However, even more complex questions } \\
\text { can be generated. }\end{array}$ & Why is power an intrinsic rather than extrinsic property? \\
\hline $\begin{array}{l}\text { 16.... because light can travel through a } \\
\text { vacuum, but sound cannot }\end{array}$ & $\begin{array}{l}\text { This focuses on a distinction between sound } \\
\text { and light. }\end{array}$ & Why can we see a spaceship explode in space but not hear it? \\
\hline 17. ... because it can be reflected & $\begin{array}{l}\text { Reflection is itself an interesting property of } \\
\text { both light and sound. }\end{array}$ & $\begin{array}{l}\text { Why can a person see themselves in a mirror? } \\
\text { How do echoes form? }\end{array}$ \\
\hline \multicolumn{3}{|l|}{ Earth Science } \\
\hline $\begin{array}{l}\text { 18. ... because a fossil is evidence of life } \\
\text { from pre-human history }\end{array}$ & $\begin{array}{l}\text { In this answer, we could dispel the myth that a } \\
\text { fossil has been petrified. }\end{array}$ & Why is a mammoth footprint a fossil? \\
\hline $\begin{array}{l}\text { 19. ... because rock can be } \\
\text { deformed by an extreme } \\
\text { pressure and heat }\end{array}$ & & $\begin{array}{l}\text { Is rock a perfect solid? } \\
\text { How are mountains pushed upwards? }\end{array}$ \\
\hline $\begin{array}{l}20 . . . \text { because the earth's } \\
\text { surface is continually } \\
\text { being regenerated }\end{array}$ & $\begin{array}{l}\text { The idea of the earth's surface being a dynamic } \\
\text { system is at the heart of this answer. }\end{array}$ & Why are there fossils of sea creatures at the top of mountains? \\
\hline \multicolumn{3}{|l|}{ Mathematics } \\
\hline $21 . \ldots$ because it simplifies to $2 a+b$ & $\begin{array}{l}\text { This is a reverse form of the usual question that } \\
\text { requires a learner to simplify. }\end{array}$ & $\begin{array}{l}\text { What is the simplest form of } a+a+b \text { ? } \\
\text { What is the simplest form of } 2(a+b)-b \text { ? }\end{array}$ \\
\hline 22. ... because it is an integer & This explores the features of an integer? & Why can we count whole numbers? \\
\hline
\end{tabular}




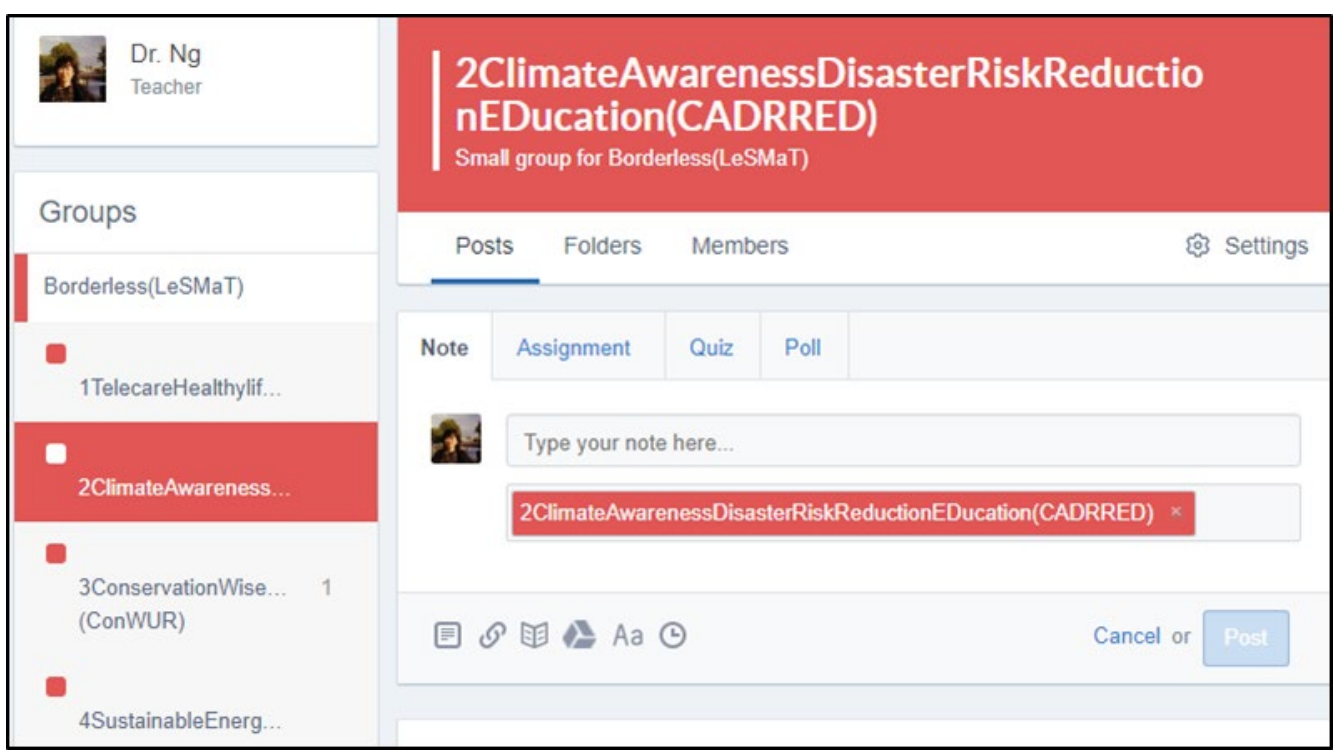

Figure 1.'Climate Awareness and Disaster Risk Reduction EDucation' (CADRRED) sub-theme under SEAMEO LeSMaT project initiative
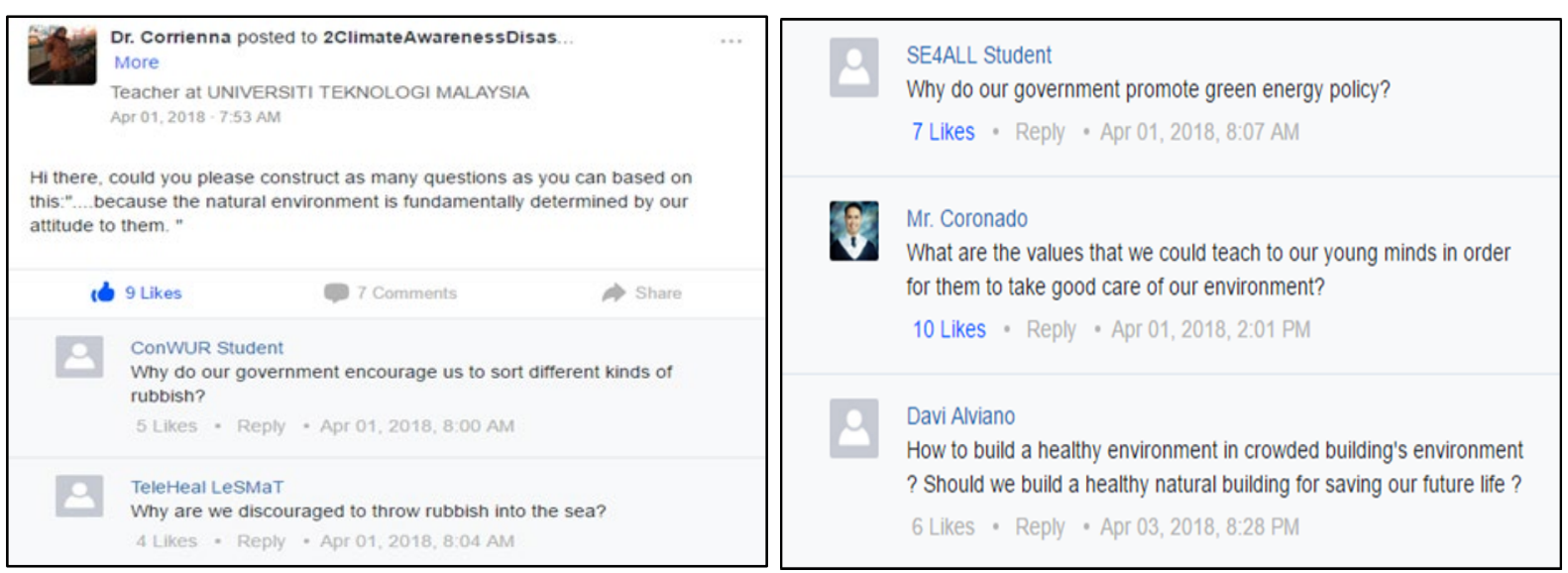

Figure 2. Post on question generating technique with responses from educators/students on 'because the natural environment is fundamentally determined by our attitude to them'

\section{Question Generating as An Approach to Promote EE-ICT: An Experience with SEAMEO School Networking Platform}

Figure 1 is the print screen of sub-theme 'Climate Awareness and Disaster Risk Reduction EDucation' (CADRRED) and other Environmental Education (EE) integrating ICT topics under SEAMEO LeSMaT networking school project initiative.

The following are the print screens of some responses from educators/ students on question generating technique (Figure 2) as posted on the Edmodo social learning platform.

\section{CONCLUSION}

In conclusion, it was revealed this generating question method was useful for learners and transformative for teacher educators and teachers in training. As a pedagogical approach, it helped develop participants' understanding of the breadth and depth of a topic eliciting responses and follow up questions helped reveal participants reasoning processes and helped reveal any misconceptions in thinking. For teacher educators and teachers in training, it emphasised the need to consider learners' responses in learning and assessment processes both in face to face environment and those supported by blended learning platforms. Ranking questions and the peer discussion, it involved helped participants to both understand the way of thinking of others and improve their metacognition. Generally, question generating method proved to be an effective method of formative assessment, 
providing much information about participants learning. We see the potential of this method for measuring both depths of understanding and development of metacognition.

\section{Summary and Implications}

We have found that younger learners find this method of working easier to engage with than older learners, and especially teachers, who find it difficult to create multiple suggestions. This could be due to a 'fear of failure' and concern about producing one best answer, echoing the focus on answering exam questions.

In addition, the creation of partial answers as the stimulus requires teachers to think at different levels at the same time and to value responses at different levels, not just looking for the right answer. This approach could therefore, be valuable in Professional Development courses for developing pedagogical content knowledge, especially those supported by blended learning platforms where learning activities do not necessarily have to be synchronised as in a face to face environment but could also be conducted over time. The advantage of blended learning platforms is that student thinking is automatically recorded and so it is possible to gain insight into how learners develop an understanding anytime anywhere. This may be more refreshing than using more traditional approaches that were not supported by digital tools. It may also be an environment that is less threatening than a traditional classroom. A common problem for teachers, especially in pre-service education, is the understanding of the progression of ideas within a topic and comprehending what others find easy or difficult. There is a tendency for teachers to assume that others think the same as what they do. The question generating method (especially including the peer discussion elements) that is either conducted face-to-face or asynchronously supported by blended learning platform as suggested in this study, can help to broaden the understanding of Environmental Education issues related to social justice.

\section{Limitation and Suggestions for Further Studies}

We found that 'creating partial answers that were sufficiently broad enough to encourage a variety of questions, yet focused enough to keep responders on the topic' was a challenge. Especially for developing awareness of EE and global issues. This method was developed initially to provide formative information with content knowledge for pupils and for PCK in teachers in training, extending it to help develop student viewpoints in EE is an additional challenge. Perhaps we could imagine even more progressively involving students in social justice questions by the kinds of part of responses we provided, although we did not manage to do so in this study. These questions would need to elicit responses showing a range of viewpoints as well as a range of content knowledge. Among these types of questions include such as:

... because low-skilled, pre-historic miners only had a short life expectancy in their unsafe environment.

... because early expert craft-workers were in short supply.

... because delicate personal craft skills were being replaced by machinery.

We propose this method of Question generating as a useful method for formative assessment both for pupils and for teachers in training. It is particularly suited to being supported by blended learning platforms and digital tools. It provides insights into the way in which participants are thinking about a content area, giving information about the depth and security of understanding and potentially revealing misconceptions. The emphasis on discussion within the activity helps to build metacognition and encourage creative thinking. Together, these are an effective method for developing teachers' pedagogical content knowledge (PCK) sustainable through blended learning platforms to promote EE supported by ICT.

\section{REFERENCES}

Berry, J. W., \& Chew, S. L. (2015). Improving Learning through Interventions of Student-Generated Questions and Concept Maps. Teaching of Psychology, 35, 305-312. https:/ / doi.org/10.1080/00986280802373841

Black, P., \& Wiliam, D. (2005). Inside the black box: Raising standards through classroom assessment. Granada Learning.

Black, P., Harrison, C., Lee, C., Marshall, B., \& Wiliam, D., 2004. Working inside the black box: Assessment for learning in the classroom. Phi delta kappan, 86(1), 8-21. https://doi.org/10.1177/003172170408600105

Cooper, F. (2018). A Modification of Think Pair Share to Make it More Learner-Centered by Using StudentGenerated Questions. College Teaching, 66(1), 34. https:// doi.org/10.1080/87567555.2017.1390438

Corrienna, A. T., \& Mohd Imran Arif, M. A. (2016). What-How-Why: A framework for thinking and learning through learner-generated questions to enhance teachers and students critical thinking. 3 ${ }^{\text {rd }}$ I-PHEX 2016, CEE Book Series, UTM, Johor. 
Creswell, J. W. (2012). Educational research: Planning, conducting and evaluating quantitative and qualitative research (4 $4^{\text {th }}$ ed.), Boston: Pearson.

Dunlop, L., Compton, K., Clarke, L., \& McKelvey-Martin, V. (2015). Child-led inquiry in primary science. Education. 3-13, 43(5), 462-481. https:// doi.org/10.1080/03004279.2013.822013

Fauville, G. (2017). Questions as indicators of ocean literacy: students' online asynchronous discussion with a marine scientist. International Journal of Science Education, 39(16), 2151-2170. https:/ / doi.org/10.1080/09500693.2017.1365184

Harlen, W., \& James, M. (1997) Assessment and Learning: differences and relationship between formative and summative assessment. Assessment in Education: Principles, Policy $\mathcal{E}$ Practice, 4(3), 365-379. https:/ / doi.org/10.1080/0969594970040304

Lombard, F. E., \& Schneider, D. K. (2013). Good student questions in inquiry learning. Journal of Biological Education, 47(3), 166-174. https:/ / doi.org/10.1080/00219266.2013.821749

MacLellan, E., \& Soden, R. (2003). Expertise, expert teaching and experienced teachers' knowledge of learning theory. Scottish Educational Review, 35(2), 110-120.

Mezirow, J. (1991). Transformative dimensions of adult learning. Jossey-Bass, 350 Sansome Street, San Francisco, CA 94104-1310.

Montecillo, P. L., Boey, M. L., Febro, R., Ng, K. T., Aligaen, J. C., Baharulnizam, B., \& Mohamad, R. (2016). Chapter 11: Optimizing the use of blended learning platform in monitoring and evaluating Disaster Risk Reduction Education. In KT Ng, R.P. Devadason \& Y.F. Lay (Eds.) (2016). Learning Science and Mathematics Together (LeSMaT) in a Borderless World Using Technology. Penang, Malaysia: SEAMEO RECSAM.

Ng, K. T., Devadason, R. P., \& Lay, Y. F. (Eds.) (2016). Learning Science and Mathematics Together (LeSMaT) in a Borderless World Using Technology. Penang, Malaysia: SEAMEO RECSAM.

Virgin, R. (2015). Customize Learning with Student-generated Guiding Questions. The Clearing House: A Journal of Educational Strategies, Issues, and Ideas, 88(3), 96-100. https:// doi.org/10.1080/00098655.2015.1032193

White, R. T., \& Gunstone, R (1992). Probing Understanding Chapter 10 Question Production. Routledge Abingdon, Oxford, UK, pp 158-176.

\section{http://www.ejmste.com}

